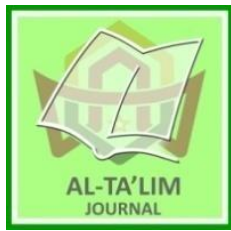

\title{
The Development of Predict Observe Explain (POE)-based Thematic Teaching Materials
}

Received: $14^{\text {th }}$ May 2018; Revised: $04^{\text {th }}$ September 2018; Accepted: $26^{\text {th }}$ November 2018

Permalink/DOI: http://dx.doi.org/10.15548/ jt.v25i3.464

\section{Amalia Puspa Rini*)}

Universitas Sebelas Maret, Surakarta, Indonesia.

E-mail: amaliaaapr@student.uns.ac.id

\section{Nunuk Suryani}

Universitas Sebelas Maret, Surakarta, Indonesia.

E-mail: nunuksuryani@staff.fkip.uns.ac.id

\section{Siti Sutarmi Fadhilah}

Universitas Sebelas Maret, Surakarta, Indonesia.

E-mail: fadh.sant@gmail.com

*) Corresponding Author

\begin{abstract}
The learning process cannot be separated from the use of teaching materials that play a role to achieve the competencies that must be achieved by the learners. The purpose of this research is to identify the developmental stages of Predict Observe Explain (POE)-based thematic teaching materials, quality, and effectiveness of teaching materials to improve the learners' learning outcomes. This is a research and development technique. The development of this product is done through the design model of ADDIE learning system, i.e. (1) analysis, (2) design, (3) development, (4) implementation, (5) and evaluation. The results show that the POE-based thematic teaching materials has excellent quality on aspects of graphics and material with the score 4.52 and score 4.75 respectively from the aspects of readability, linguistic, and presentation according to the learners as the users of the product. Furthermore, the effectiveness test results show that the average class score that does not use POEbased thematic materials is 75.72, whereas that using POE thematic materials is 82.08 . Therefore, the average score in the experimental class is higher than the control one. The Sig. shows $0.010<0.05$, then $\mathrm{H}_{0}$ is rejected and $\mathrm{H}_{1}$ accepted. It is concluded that there is a significant value difference between the control and experimental class.
\end{abstract}

Keywords: Teaching materials; thematics; POE

How to Cite: Rini, A. P., Suryani, N., \& Fadhilah, S. S. (2018). Development of predict observe explain (POE)based thematic teaching materials. Al-Ta Lim Journal, 25 (3). doi: http://dx.doi.org/10.15548/ jt.v25i3.464

\section{INTRODUCTION}

Education is one of the benchmarks of the progress of a nation (Taylor, Gillborn, \& Ladson-Billings, 2009). High quality of human resources (HR) in a country can be correlated with the quality of good education (Haynes \& Fryer, 2000; Noe, Hollenbeck, Gerhart, \& Wright, 2017; Sun, Aryee, \& Law, 2007). Therefore, a good education process is required so that Indonesia can compete not only in the life of society nationally and globally.
Aisyah, (2015); Fatimah, (2006); Sumantri \& Permana, (2001) stated that elementary school is the level of education in Indonesia that has a very important role in efforts to improve the quality of human resources (HR). According to Buhler (2013), the stage of children's development lasts between 9-11 years, when they already have high objectivity, and it can also be called a period of investigating, trying and experimenting, stimulated by probing impulses with great curiosity, the concentration and hoarding period for training 
and exploring. Based on these statements, it can be concluded that the fourth grade of elementary school students are at the age of 910 years, who has the characteristics as previously stated more or less (Markova', 2000; Prihantoro, 2015).

Currently, Indonesia is in a transition era, from the use of educational curriculum called Education Unit Level Curriculum (KTSP) to Curriculum 2013. The implementation of Curriculum 2013 at elementary level in learning using thematic approaches is applied for class I to class VI. Because the curriculum is still relatively new, the existing teaching materials are also still very limited, so the development of teaching materials is very important, considering that the curriculum will be effective nationally in 2018. In fact, the success of a teacher in implementing the thematic learning depends on his insight, knowledge, and level of creativity in managing the teaching materials (Al-Tabany, 2011; Hanifah, 2014; Puspitasari, 2012; Sulistiani \& Mustami'ah, 2016; Trianto, 2016)

In addition to the use of teaching materials, the existence of appropriate and interesting teaching models, techniques, or strategies which are then implemented in conjunction with the teaching materials will also affect the learners' interest in attending the class.

One effort that can be done to achieve such learning is to design a learning resource based on Predict Observe Explain (POE). POE is a learning technique introduced by White and Gunstone (Haysom \& Bowen, 2010; Kala, Yaman, \& Ayas, 2013; Kearney, 2004; Kearney, Treagust, Yeo, \& Zadnik, 2001; Liew, 2004). This instructional technique is based on constructivism learning theory which assumes that through the activities of prediction, observation, and explaining the results of observation, the cognitive structure will be formed well (Darimi, 2016; Fathurrohman, 2015; Nurdyansyah \& Fahyuni, 2016; Silberman, 2009; Warsono \& Hariyanto, 2012; Zaini, Munthe, \& Aryani, 2008). This is supported by a research conducted by (Nuraini \& Karyanto, 2014) which shows that the development of POE-based modules along with Roundhouse Diagram is effective and can influence the scientific process skills (KPS) and the learners' ability to explain during Biology learning.

This is supported by the results of interviews and preliminary observations made on the learning activities undertaken by the teachers and students of class IV SD Negeri Mendala 02 and SD Negeri Mendala 01. Based on the results, it can be concluded that the teaching materials used are only obtained from the government. The teaching materials used are in the form of thematic materials as the supporters of the implementation of Curriculum 2013 which is still being carried out any revisions.

In addition, the development of teaching materials is still low, so that the students' understanding is less depth. Furthermore, it is also known that the learners often feel confused to learn the materials available in the teaching materials because there is no summary of materials and exercises at the end of learning activities that can be used obtain better understanding. Therefore, the learning outcomes have not been yet maximized. It can be seen from the average scores of daily test on the theme of Beautifulness Togetherness, sub-theme of Cultural Diversity, Bahasa Indonesia, Natural Sciences, and Social Sciences which have not yet reached Minimum Score Criteria (KKM) determined by the school, i.e. 75 . The scores are presented in Table 1 below:

Table 1. Daily Test Scores

\begin{tabular}{ccc}
\hline Subject & $\begin{array}{c}\text { SD Negeri } \\
\text { Mendala 01 }\end{array}$ & $\begin{array}{c}\text { SD Negeri } \\
\text { Mendala 02 }\end{array}$ \\
\hline $\begin{array}{c}\text { Bahasa } \\
\text { Indonesia } \\
\text { Natural }\end{array}$ & 73,46 & 71,19 \\
$\begin{array}{c}\text { Sciences } \\
\text { Social }\end{array}$ & 71,19 & 70,45 \\
Sciences & 71,60 & 70,74 \\
\hline
\end{tabular}

Based on the description above, it can be formulated some research questions: (1) 
how is the development procedure of POEbased thematic materials?; (2) how is the quality of the products of POE-based thematic teaching materials?; (3) Are POE-based thematic materials effective for improving the learners' learning outcomes?

The objectives of this research are: (1) to identify the development procedure of POE-based thematic teaching materials; (2) to identify the quality of POE-based thematic products; (3) to identify the effectiveness of POE-based thematic materials to improve the learners' learning outcomes.

\section{Teaching Materials}

According to Dick, Carey, \& Carey (2005), teaching materials are a set of materials/substances systematically arranged, displaying a complete figure of competence that should be mastered by the learners in the learning activities. Furthermore, the National Center for Competency Based Training Andi (2014) states that teaching materials are all forms of materials used to assist the teachers or instructors in carrying out the learning process in the classroom. The materials in question can be either written or unwritten. Next, Al Azri \& Al-Rashdi (2014); Davis \& Wilcock (2003) explains that teaching materials are all materials (information, tools, and texts) systematically arranged, showing the whole figure of competence that should be mastered by the learners and used in the learning process to plan and review the learning implementation. This is in line with the opinion of Johar \& Hanum (2016) who states that teaching materials are all forms of materials arranged systematically and used to help the teachers or instructors in carrying out the teaching and learning activities that create conducive environment or atmosphere that allows the learners to learn optimally.

From some opinions above, it can be concluded that teaching materials are a set of materials / substances (information, tools, and text) systematically arranged to assist the teachers or instructors in the learning process, so that the learners are able to master certain competencies based the purposes of planning and reviewing the learning implementation.

\section{Thematic Learning}

Thematic is defined as "matters related with the theme"; and the "theme" itself means "the main idea; the basis of the story (spoken, used as the basis of making up, altering poetry, etc.) (Clarke \& Braun, 2013)." Furthermore, Trianto (2016) explains that thematic learning is interpreted as a learning that is designed based on certain themes. In the discussion, the theme is viewed from various subjects. Next, Daryanto (2014) argues that thematic learning is defined as the learning that uses themes to link some subjects to provide meaningful experiences for the students.

Based on the opinions above, it can be concluded that thematic learning is learning designed with respect to certain themes viewed from various subjects with the aim to provide meaningful experience for the learners.

\section{Predict Observe Explain (POE)}

Fannie \& Rohati (2014); Hilario (2015) suggest that POE is a learning technique introduced and developed by White and Gunstone. This learning technique is based on the theory of constructivism learning which assumes that through activities of prediction, observation, and explaining the results of observation, the cognitive structure will be formed properly. This is in line with the opinion of Coştu, Ayas, \& Niaz (2012); Sesen (2013)who explains that using by POE technique is based on constructivism learning theory, that is, by exploring knowledge that has been acquired or obtained previously and then interpreting it.

Karamustafaoğlu \& Mamlok-Naaman (2015) explains, "POE strategy is an inevitable way to make science courses more interesting, to induce permanent learning, and to eliminate misconceptions.". The statement can be interpreted that the learning done by 
using POE technique can make science learning becomes more fun, make learning more inherent for the students because they will get involved in the learning process, and avoid or eliminate their misconceptions.

Besides, according to Hsu, Tsai, \& Liang (2011); Kibirige, Osodo, \& Tlala (2014), learning by using POE technique is efficient to create some discussions about the concept of science, because POE learning technique involves the students in predicting certain phenomena, observing through demonstrations or experiments, and ultimately explaining the results of their previous demonstrations and forecasts. Based on some statements above, it can be concluded that $\mathrm{POE}$ is a learning technique built based on constructivism theory. Learning theory is done by exploring the knowledge that has been obtained or owned by students before and then interpreting it through some activities to predict the experiments to be performed. Furthermore, observations are made to test the accuracy of predictions made, and to explain the observation results that have been done, whether in accordance with the initial prediction that has been made or not.

\section{METHOD}

The technique applied was Research and Development. Gall, Borg, \& Gall (1996) defined that Educational research and development ( $R \& D)$ is a process used to develop and validate educational products. Goal of educational research is not to develop products, but rather to discover new knowledge (through basic research) or to answer specific questions about practical problems (through applied research). Based on the statement, it can be understood that the research and development in education is a process used to develop and validate educational products and not to develop products, but to discover new knowledge (through basic research) or to answer specific questions about practical issues (through applied research). This research used descriptive method on its preliminary observation to collect the data about existing conditions, and evaluative method was used to evaluate the process of product development trial. The product was developed through a series of trials, and each test activity was evaluated, both on the results and process.

Based on the findings during the experiments, a refinement was made. Next, the experimental method was used to test the resulting product. The development procedure in this study was adapted from ADDIE learning system design, i.e. (1) analysis, (2) design, (3) development, (4) implementation, (5) and evaluation. This development research started with the analysis phase, including a preliminary study consisting of interviews, field observations, and literary review of the latest curriculum.

Furthermore, the design phase aimed to design the product based on the results of the analysis obtained. Once designed, the development was carried out to identify weaknesses of the initial product that has been designed through two stages: (1) expert validation and (2) trials/experiments. The data obtained in this study were quantitative, from the expert validation questionnaires, one-toone, small group, and field tests. The data of the experts, one-to-one, small group, and field tests were used to determine the feasibility of the product. The data analysis technique used was descriptive statistical. Quantitative data were then converted into qualitative one using scale 5 as follows.

Table 2. Conversion Quantitative Data into Qualitative

\begin{tabular}{ccc}
\hline Interval Score & Score & Category \\
\hline$X>4,21$ & 5 & Very Good \\
$3,40<X \leq 4,21$ & 4 & Good \\
$2,60<X \leq 3,40$ & 3 & Fair \\
$1,79<X \leq 2,60$ & 2 & Poor \\
$X \leq 1,79$ & 1 & Very Poor \\
\hline
\end{tabular}

After going through experts' validation and users' trials, POE-based thematic materials went to the field test. The control class was from SD Negeri Mendala 01 with 25 students, while the experimental one was SD Negeri Mendala 02 with 25 students. 
For the final step, an evaluation was conducted to determine whether POE-based teaching materials products were more effective than the materials currently used in learning. The teaching materials developed could be said to be more effective if there was a significant difference in the learning outcomes on the theme of Indahnya Kebersamaan (Beauty of Togetherness) and sub-theme of Ragam Budaya Bangsaku (Cultural Diversity of My Country) between the control and experiment classes.

\section{RESULT AND DISCUSSION}

This research is conducted through five steps, namely (1) analysis, (2) design, (3) development, (4) implementation, and (5) evaluation.

Analysis

The results of the research include the analysis of the needs obtained from interviews and observations on the fourth grade teachers of SD Negeri Mendala 01 and SD Negeri Mendala 02, validation of teaching materials by media and material experts, and one-on-one test of three students, small groups of 10 students, and field test of 20 students.

Based on the results of interviews and observations, it can be concluded that the thematic materials used are only taken from the government. The teachers feel that the development of materials in the teaching materials is not yet maximum, so the students' understanding is also not deep enough. Furthermore, it is also known that the learners feel confused to learn the existing materials in these teaching materials because there is no summary of materials and exercises at the end of each learning activity that can be used to reach better understanding.

Design

The product is a POE-based thematic material which is then designed based on the learning outcomes to be achieved.

\section{Development}

Next, the initial product is developed to identify its weaknesses through two stages, namely experts' validation and trials. The data of the validation of media experts, materials experts, and one-on-one test of three students, small group test of ten participants, and field test of twenty students are presented in the following table.

Table 3. Result of Validation from Media and Material Experts

\begin{tabular}{ccccc}
\hline Assessment & I & II & Average & Category \\
\hline Media Expert & 4,30 & 4,44 & 4,37 & $\begin{array}{c}\text { Very } \\
\text { Good }\end{array}$ \\
\hline $\begin{array}{c}\text { Material } \\
\text { Experts }\end{array}$ & 4,44 & 4,77 & 4,66 & $\begin{array}{c}\text { Very } \\
\text { Good }\end{array}$ \\
\hline \multicolumn{2}{c}{ Average } & & 4,52 & $\begin{array}{c}\text { Very } \\
\text { Good }\end{array}$ \\
\hline
\end{tabular}

Based on Table 3, it can be seen that the average score of product assessment conducted by media experts assessing the aspect of graphics is 4,37, and the average score of product assessment conducted by material experts who assess the material aspect is 4,66 , so that the average score of the experts' validation is 4,52 .

Table 4. Results of One-on-One Test, Small Group Test, and Field Test

\begin{tabular}{ccc}
\hline Assessment & Average & Category \\
\hline $\begin{array}{c}\text { One-on-One (3 } \\
\text { participants) }\end{array}$ & 4,84 & Very Good \\
$\begin{array}{c}\text { Small Group (10 } \\
\text { participants) }\end{array}$ & 4,61 & Very Good \\
$\begin{array}{c}\text { Field Test (20 } \\
\text { participants) }\end{array}$ & 4,80 & Very Good \\
\hline
\end{tabular}

Based on Table 4, it can be seen that the average score of product assessment of one-to-one test is 4,84 , the average score of product assessment from the small group test is 4,61and the average score of product assessment from the field test is 4,80. The experts' validation results, one-on-one, small group, and field test are summarized in Table 5 below. 
Table 5. Summary of Feasibility Test of the Product

\begin{tabular}{cccc}
\hline No & Feasibility Test & $\begin{array}{c}\text { Average } \\
\text { Score }\end{array}$ & Category \\
\hline 1 & $\begin{array}{c}\text { Experts' } \\
\text { Validation }\end{array}$ & 4,52 & Very good \\
\hline 2 & One-on-one Test & 4,84 & Very good \\
\hline 3 & Small Group Test & 4,61 & Very good \\
\hline 4 & Field Test & 4,80 & Very good \\
\hline Overall Average Score & 4,69 & Very good \\
\hline
\end{tabular}

Thus, it can be concluded that from the results of experts' validation and product testing, POE-based thematic teaching materials have excellent quality and appropriate for to be applied for the fourth grade students of elementary school on the theme of Indahnya Kebersamaan (Beauty of Togetherness) and the sub-theme of Keragaman Budaya Bangsaku (Cultural Diversity of My Country). The results are supported by the research conducted by Widyaningrum, Sarwanto, \& Karyanto (2013) who concluded that the development of POEoriented module that requires the learners to predict, observe, and explain the results of observation will help them in various forms of learning.

\section{Implementation}

The product implementation is carried out after the product has passed the development stages which include experts' validation, one-on-one, small group, and field tests. In the implementation stage, the product is tested to find out whether it has been developed effectively to improve the learning outcomes. The product to be tested is the product of the development process (final product). This product test uses a control class that is not given any treatment (using POEbased teaching materials) and the experimental one is taught using POE-based thematic teaching materials. The classes used for the research are the students of SD Negeri Mendala 01 as the control class and the students of SD Negeri Mendala 02 as the experimental one, and they have experienced prerequisite test which included normality, homogeneity, and equality tests. The summary of the equivalence test is shown in Table 6 below.
Table 6. Summary of Equivalence Test

\begin{tabular}{llcc}
\hline & \multicolumn{1}{c}{ Tests } & Sig. & Result \\
\hline a. & Normality & & \\
& Control Group & 0,093 & Normal \\
& Experiment Group & 0,614 & Normal \\
b. & Homogenity & 1,000 & Homogenous \\
c. & Equivalence & 0,561 & Equivalent \\
\hline
\end{tabular}

Table 6 shows that each class in SD Negeri Mendala 01 and SD Negeri Mendala 02 is normal, homogeneous, and equal. To determine whether the average scores of the learning outcomes for the control and experiment classes are different significantly, a statistical test called Independent Samples T-Test is conducted. The use of the test requires two prerequisite tests that must be met, normality and homogeneity.

The results of statistical test show that there is difference of average scores of learning result between the control and experiment class. The results of the Independent Samples T-Test are shown in Table 7 below.

Table 7. Results of Effectiveness Tests using Independent Samples T-Test

\begin{tabular}{lccc}
\hline \multicolumn{1}{c}{ Types of Tests } & Score & Sig. & Result \\
\hline $\begin{array}{l}\text { a. Normality } \\
\text { Test }\end{array}$ & & & \\
$\begin{array}{l}\text { Control } \\
\text { Group }\end{array}$ & 75,72 & 0,145 & Normal \\
$\begin{array}{l}\text { Experiment } \\
\text { Group }\end{array}$ & 82,08 & 0,967 & Normal \\
$\begin{array}{l}\text { b. Homogenity } \\
\text { Test }\end{array}$ & & 0,522 & $\begin{array}{c}\text { Homo- } \\
\text { genous }\end{array}$ \\
& & $\begin{array}{c}\text { Sig }(2- \\
\text { tailed })\end{array}$ & \\
& & & $\begin{array}{c}\mathrm{H}_{0} \text { is } \\
\text { rejected } \\
\text { and }\end{array}$ \\
$\begin{array}{l}\text { c. Effectiveness } \\
\text { Test }\end{array}$ & & 0,010 & $\mathrm{H}_{1}$ accep \\
& & & t-ed \\
\hline
\end{tabular}

Table 7 shows that each class in SD Negeri Mendala 01 and SD Negeri Mendala 02 is normal and homogeneous. Furthermore, based on the effectiveness test, it is obtained the significance value. (2-tailed) is 0,010 $<0,05$ which means $\mathrm{H}_{0}$ is rejected and $\mathrm{H}_{1}$ is accepted. Because the value of Sig. <0,05, hence it can be concluded that there is significant difference of the average scores on 
the learning outcomes between the control and experiment classes.

The results are in line with Dewi (2015) who stated that the developed POE Biology module is able to empower the students' critical thinking skills, cognitive learning outcomes, and motivation. This can be seen from the result of paired t-test of the pre-test and post-test on the students' critical thinking ability which shows the level of significance $0.000<0,05$ which means there is difference results between the pre-test and post-test scores on the critical thinking ability. Similarly, the paired t-test results from the pre-test and post-test on the students' motivation show the significance level of $0.000<0.05$, it means there are differences in pre-test and post-test scores. Furthermore, the paired t-test results from the pre-test and posttest on the cognitive learning outcomes show a significance level of $0.000<0.05$ which means there is a difference in pre-test and post-test scores on the students' cognitive learning outcomes.

\section{Evaluation}

Based on the effectiveness test, the average score obtained from the class that does not use POE thematic materials is 75,72 , while that using the POE is 82,08 . Thus, the average score in the experimental class is higher than the control one. Sig. shows 0,010 $<0,05$, then $\mathrm{H}_{0}$ is rejected and $\mathrm{H}_{1}$ is accepted. Therefore, it can be concluded that there is a significant difference between the control and the experimental class, so that POE thematic teaching materials are effective to improve the students' learning outcomes of class IV on the theme of Indahnya Kebersamaan (Beauty of Togetherness) with the sub-theme of Keberagaman Budaya Bangsaku (Cultural Diversity of My Country)

\section{CONCLUSION AND RECOMMENDATION}

Based on the results and discussion that have been described, it can be concluded that the Predict Observe Explain (POE)-based teaching materials are developed based on the analysis of the need for the availability of teaching materials referring to the Curriculum 2013. The teaching materials are developed through the steps of ADDIE learning system design model, including (1) analysis, (2) design, (3) development, (4) implementation, (5) and evaluation.

The media experts' test average score is 4,37, while the average score of the material experts is 4,66 , so that the average score of the experts' tests is 4,52. Next, the score obtained on the feasibility of POEthematic themed materials on the one-on-one test is 4,84 (very good), small group test has the average score of 4,61 (very good), and the field test obtained 4,80 (very good). Therefore, it can be concluded that POEbased thematic teaching materials are effective to be used for the learning activities of the students of class IV elementary school on the theme of Indahnya Kebersamaan (Beauty of Togetherness) with the sub-theme of Keragaman Budaya Bangsaku (Cultural Diversity of My Country).

The effectiveness test results show that there is a significant difference between the control and the experimental classes. Based on the research results, the writers suggest some points: (1) the teachers should have adequate ability to write, so that the weaknesses found in textbooks provided by the government can be reduced; (2) the schools need to provide sufficient learning resources to support the learning so that the learners will be able to gain rich knowledge and deep understanding; (3) The Department of Education as a government agency that directly takes care of the teachers needs to provide opportunities and facilities to improve their professionalism through courses, training, or further studies.

\section{REFERENCES}

Aisyah, S., \& Ag, S. (2015). Perkembangan peserta didik dan bimbingan belajar. Deepublish. 
Al Azri, R. H., \& Al-Rashdi, M. H. (2014). The effect of using authentic materials in teaching. International Journal of Scientific \& Technology Research, 3(10), 249-254.

Al-Tabany, T. I. B. (2011). Desain Pengembangan Pembelajaran Tematik Bagi Anak Usia Dini TK. RA \& Anak Usia Kelas Awal SD/MI, Jakarta: Prenadamedia Group.

Andi, P. (2014). Pengembangan Bahan Ajar Tematik Tinjauan Teoritis dan Praktis. Jakarta: Kencana Prenadamedia Group.

Buhler, K. (2013). The mental development of the child: A summary of modern psychological theory. Routledge.

Clarke, V., \& Braun, V. (2013). Teaching thematic analysis: Overcoming challenges and developing strategies for effective learning. The Psychologist, 26(2), 120-123.

Coştu, B., Ayas, A., \& Niaz, M. (2012). Investigating the effectiveness of a POE-based teaching activity on students' understanding of condensation. Instructional Science, 40(1), 47-67.

Darimi, I. (2016). Diagnosis Kesulitan Belajar Siswa Dalam Pembelajaran Aktif di Sekolah. Jurnal Edukasi: Jurnal Bimbingan Konseling, 2(1), 30-43.

Daryanto, D. (2014). Pengembangan Perangkat Pembelajaran. Yogyakarta: Gava Media.

Davis, C., \& Wilcock, E. (2003). Teaching materials using case studies. C. Baillie (Series Ed.), The UK Centre for Materials Education.

DEWI, E. R. (2015). Pengembangan modul biologi sma/ma berbasis poe untuk memberdayakan kemampuan berpikir kritis dan motivasi belajar siswa pada materi pencemaran lingkungan (Studi
Pembelajaran pada Materi Pencemaran Lingkungan Kelas $X$ Semester Genap di SMA $N \quad 1$ Kedunggalar Tahun Pelajaran 2013/2014) (PhD Thesis). Universitas Sebelas Maret.

Dick, W., Carey, L., \& Carey, J. O. (2005). The systematic design of instruction.

Fannie, R. D., \& Rohati, R. (2014). Pengembangan lembar kerja siswa (LKS) berbasis POE (predict, observe, explain) pada materi program linear kelas XII SMA. Sainmatika: Jurnal Sains Dan Matematika Universitas Jambi, 8(1).

Fathurrohman, M. (2015). Model-Model Pembelajaran. Universitas Negeri Yogyakarta. Jogjakarta: Ar-Ruzz Media. Retrieved From.

Fatimah, E. (2006). Perkembangan Peserta Didik. Pustaka Setia: Bandung, 149159.

Gall, M. D., Borg, W. R., \& Gall, J. P. (1996). Educational research: An introduction. Longman Publishing.

Hanifah, T. U. (2014). Pemanfaatan Media Pop-Up Book Berbasis Tematik untuk Meningkatkan Kecerdasan VerbalLinguistik Anak Usia 4-5 Tahun (Studi Eksperimen di TK Negeri Pembina Bulu Temanggung). BELIA: Early Childhood Education Papers, $3(2)$.

Haynes, P., \& Fryer, G. (2000). Human resources, service quality and performance: a case study. International Journal of Contemporary Hospitality Management, 12(4), 240-248.

Haysom, J., \& Bowen, M. (2010). Predict, observe, explain: Activities enhancing scientific understanding. NSTA Press.

Hilario, J. S. (2015). The Use of PredictObserve-Explain-Explore (POEE) as a 
New Teaching Strategy in General Chemistry Laboratory. ISSN Journal, 37-48.

Hsu, C.-Y., Tsai, C.-C., \& Liang, J.-C. (2011). Facilitating preschoolers' scientific knowledge construction via computer games regarding light and shadow: The effect of the predictionobservation-explanation (POE) strategy. Journal of Science Education and Technology, 20(5), 482-493.

Johar, R., \& Hanum, L. (2016). Strategi belajar mengajar. Deepublish.

Kala, N., Yaman, F., \& Ayas, A. (2013). The effectiveness of predict-observeexplain technique in probing students' understanding about acid-base chemistry: a case for the concepts of $\mathrm{PH}, \mathrm{POH}$, and strength. International Journal of Science and Mathematics Education, 11(3), 555-574.

Karamustafaoğlu, S., \& Mamlok-Naaman, R. (2015). Understanding electrochemistry concepts using the predict-observe-explain strategy. Eurasia Journal of Mathematics, Science and Technology Education, 11(5), 923-936.

Kearney, M. (2004). Classroom use of multimedia-supported predictobserve-explain tasks in a social constructivist learning environment. Research in Science Education, 34(4), 427-453.

Kearney, M., Treagust, D. F., Yeo, S., \& Zadnik, M. G. (2001). Student and teacher perceptions of the use of multimedia supported predictobserve-explain tasks to probe understanding. Research in Science Education, 31(4), 589-615.

Kibirige, I., Osodo, J., \& Tlala, K. M. (2014). The effect of predict-observe-explain strategy on learners' misconceptions about dissolved salts. Mediterranean Journal of Social Sciences, 5(4), 300.
Liew, C.-W. (2004). The effectiveness of predict-observe-explain technique in diagnosing students' understanding of science and identifying their level of achievement ( $\mathrm{PhD}$ Thesis). Curtin University.

Markova', I. (2000). The individual and society in psychological theory. Theory \& Psychology, 10(1), 107116.

Noe, R. A., Hollenbeck, J. R., Gerhart, B., \& Wright, P. M. (2017). Human resource management: Gaining a competitive advantage. McGraw-Hill Education New York, NY.

Nuraini, N., \& KARYANTO, P. (2014). Pengembangan Modul Berbasis POE (Predict, Observe, and Explain) Disertai Roundhouse Diagram untuk Memberdayakan Keterampilan Proses Sains dan Kemampuan Menjelaskan Siswa Kelas X SMA Negeri 5 Surakarta (Penelitian dan Pengembangan Materi Pencemaran Lingku. BIOEDUKASI, 7(1).

Nurdyansyah, N., \& Fahyuni, E. F. (2016). Inovasi Model Pembelajaran Sesuai Kurikulum 2013. Nizamia Learning Center.

Prihantoro, C. R. (2015). The perspective of curriculum in Indonesia on environmental education. International Journal of Research Studies in Education, 4(1), 77-83.

Puspitasari, E. (2012). Menyusun Perencanaan Pembelajaran Anak Usia Dini. Jurnal Educhild: Pendidikan Dan Sosial, 1(1), 67-76.

Sesen, B. A. (2013). Diagnosing pre-service science teachers' understanding of chemistry concepts by using computer-mediated predict-observeexplain tasks. Chemistry Education Research and Practice, 14(3), 239246. 
Silberman, M. (2009). Active Learning: 101 strategi pembelajaran aktif. Yogyakarta: Pustaka Insan Madani.

Sulistiani, W., \& Mustami'ah, D. (2016). Efektivitas Modul Pembelajaran Tematik Kelautan dan Kemaritiman untuk Menumbuhkan Minat Kebaharian pada Anak Usia Dini di Taman Kanak-Kanak. In Prosiding Seminar Asean Psychology \& Humanity, $\quad$ Universitas Muhammadiyah Malang (pp. 19-20).

Sumantri, M., \& Permana, J. (2001). Strategi belajar mengajar. Bandung: $C V$. Maulana.

Sun, L.-Y., Aryee, S., \& Law, K. S. (2007). High-performance human resource practices, citizenship behavior, and organizational performance: A relational perspective. Academy of Management Journal, 50(3), 558-577.
Taylor, E., Gillborn, D., \& Ladson-Billings, G. (2009). Foundations of critical race theory in education.

Trianto, M. P. (2016). Desain Pengembangan Pembelajaran Tematik: Bagi anak Usia Dini. Prenada Media.

Warsono, H., \& Hariyanto, M. S. (2012). Pembelajaran aktif teori dan asesmen. Bandung: PT Remaja Rosdakarya.

Widyaningrum, R., Sarwanto, S., \& Karyanto, P. (2013). Pengembangan Modul Berorientasi Poe (Predict, Observe, Explain) Berwawasan Lingkungan Padamateri Pencemaran Untuk Meningkatkan Hasil Belajar Siswa. Bioedukasi: Jurnal Pendidikan Biologi, 6(1), 100-117.

Zaini, H., Munthe, B., \& Aryani, S. A. (2008). Strategi pembelajaran aktif. Yogyakarta: Pustaka Insan Madani, $58,58$. 